\title{
Oak and hornbeam pollen season in Kielce in 2021
}

\author{
Anna Kopacz-Bednarska1, Joanna Posłowska², Joanna Ślusarczyk² \\ ${ }^{1}$ Department of Medical Biology, Institute of Biology, Jan Kochanowski University in Kielce \\ ${ }^{2}$ Department of Environmental Biology, Institute of Biology, Jan Kochanowski University in Kielce
}

\begin{abstract}
:
The paper presents the characteristics of oak and hornbeam pollen seasons in Kielce in 2021. Aeropalinological measurements were carried out with the use of the volumetric method. The main oak pollen season lasted 35 days. The maximum concentration of oak pollen, i.e. 227 grains in $1 \mathrm{~m}^{3}$ of air, was recorded on May 20 $0^{\text {th }}$, and the seasonal pollen index was estimated at 1533. The hornbeam pollen season was longer, i.e. 56 days. The peak hornbeam pollen release was recorded on April 28 $8^{\text {th }}$, when 22 pollen grains in $1 \mathrm{~m}^{3}$ of air were noted, with the annual concentration sum of 207. The study also determined the effect of some meteorological factors on the concentration of pollen grains of the analyzed plant taxa. The meteorological parameters were found to exert the strongest effect on the dynamics of the hornbeam pollen season.
\end{abstract}

Key words: pollen season, oak (Quercus), hornbeam (Carpinus), meteorological factors, Kielce, 2021

\section{Introduction}

Allergic diseases are a serious health problem. The number of patients affected by various types of allergies and allergy-related diseases has been steadily increasing in recent years. Inhaled allergens, such as plant pollen, currently have great clinical importance. In Poland, pollen monitoring is carried out in various regions, mainly in urban areas. The published pollen data are an important source of information about airborne allergens for both allergic patients and allergists. Pollen allergy is typically a seasonal disease, and its course depends on the degree of exposure of the organism to the allergen [1]. Therefore, aerobiological data help to take measures to prevent organism exposure to high concentrations of pollen grains and to reduce the clinical symptoms of allergy. An important role in the profile of allergic diseases may be played by oak and hornbeam pollen allergens.

The oak (Quercus) represents the family $\mathrm{Fa}$ gaceae. It is widespread mainly in wet habitats of Europe. It also occurs across Poland, mainly in mixed forests located in river valleys [2]. The pedunculate oak (Quercus robur L.) and the sessile oak (Quercus petraea Liebl.) are common species growing in Poland. Two other species that can be found in Poland are the pubescent oak (Quercus pubescens Willd.) growing in Bielinek on the Odra River and the red oak (Quercus rubra L.), i.e. a non-native species that is an increasingly frequent element of forests and parks [2-5]. Oaks flower in spring, mainly in April and May, and the dates of pollen seasons of pedunculate and sessile oaks do not fully coincide [6]. There may be an approximately 2-week difference in the pollen seasons between these oaks.

The oak is a monoecious and anemophilous tree [7]. It is regarded as a mildly allergenic species with moderate clinical importance [3]. The main oak allergen is Que a 1 with a mass of $17 \mathrm{kDa}$ [3]. There are no precise data on the threshold concentration of oak pollen $[3,8]$. Clinical observations revealed that patients experienced discomfort at exposure to a con- 
centration of approx. 80 grains in $1 \mathrm{~m}^{3}$ of air $[3,8,9]$. The first clinical symptoms in oak pollen sensitive patients are observed after exposure of the organism to a pollen concentration equal to or exceeding the value of 16 grains in $1 \mathrm{~m}^{3}$ of air. In turn, the concentration of oak pollen grains exceeding 91 grains in $1 \mathrm{~m}^{3}$ of air is considered the threshold value inducing clinical symptoms in most patients [10]. These data have also been confirmed in the most recent publications $[5,7]$.

The hornbeam (Carpinus L.) is native to the temperate climate. There are two species of hornbeam in Europe: the common hornbeam (Carpinus betulus L.) and the eastern hornbeam (Carpinus orientalis Mill.) [11]. Only one species, i.e. the common hornbeam (Carpinus betulus L.), grows in Poland, mainly in lowland areas and higher mountain zones [12, 13]. The tree is part of mixed forests and forms oak-hornbeam stands together with oaks and limes. In parks and gardens, it is used in landscape plantings and as a complementary element in tree stands. In horticulture, the hornbeam is planted in hedges and tree lanes. The hornbeam is a monoecious tree with gonochorous flowers produced together with leaves. Its anemophilous flowers usually bloom in April and May [4, 15]. Together with hazel, the common hornbeam represents the family Corylaceae [16]. It is closely related to trees from the family Betulacea represented by birch and alder and to trees from the Fagaceae family represented by oak and beech. The homology of the structure of the antigenic proteins in their pollen is therefore high and there are cross-reactions between the members of these families [17-19].

As reported in the literature, hornbeam pollen is moderately allergenic [11]. Its importance in allergology is attributed to the potential strong cross-reactivity with allergens of other plants, e.g. alder and birch, and with food allergens, e.g. apple, peach, nuts, almonds, tomatoes, celery, and carrots. The hornbeam pollen season generally coincides with the flowering of birch, which may increase allergic reactions [11]. The main allergen in hornbeam pollen is $17-\mathrm{kDa}$ Car $b 1$ [12, 20]. As suggested by Gumowski et al. [21], hornbeam pollen is an underappreciated inhaled allergen. It is usually not included in allergy screening tests; however, simultaneous exposure of the organism to hornbeam and birch pollen may impede recognition of clinical symptoms caused by hornbeam pollen allergens [21]. The literature data show that the threshold values of hornbeam pollen concentrations inducing clinical symptoms are the same as for oak allergens ( $\geq 16$ and $\geq 91$ in $\mathrm{m}^{3}$ of air) $[10,11]$.

\section{Aim}

The aim of this study was to assess the dynamics of oak and hornbeam pollen seasons in Kielce in 2021. The study also determined the impact of some meteorological factors on the concentration of pollen grains produced by the analyzed plant taxa.

\section{Material and methods}

The study was carried out in Kielce, i.e. a city located in the Świętokrzyskie Mts region. The volumetric method with the use of a VPPS 2000 device (Lanzoni) was employed for measurements of the concentration of pollen grains. The apparatus was placed $18 \mathrm{~m}$ above ground level on the terrace of the building of the Institute of Biology, Jan Kochanowski University in Kielce. The device worked in a 7-day continuous cycle. The pollen collecting tape was changed once a week. The pollen grains were stained with alkaline fuchsin. The microscope slides were analyzed using a Nikon optical microscope $(\times 300)$. The concentration of the pollen grains was expressed in $1 \mathrm{~m}^{3}$ of air $\left(\mathrm{P} / \mathrm{m}^{3}\right)$. The following parameters were determined in the study: the length of the total pollen season, the length of the main pollen season, the total daily pollen grain concentrations during the season (SPI), the peak pollen concentration, and the dates of maximum pollen concentrations. The number of days with concentrations exceeding the plant species-specific threshold was calculated based on literature data [10]. The length of the main pollen season was determined with the $98 \%$ method, where days with $1 \%$ and $99 \%$ of the annual pollen sum were regarded as the onset and end of the season, respectively [22]. The plant pollen seasons were analyzed relative to the following meteorological factors: maximum temperature $\left(\mathrm{T}_{\max }\left[{ }^{\circ} \mathrm{C}\right]\right)$, minimum temperature $\left(\mathrm{T}_{\min }\left[{ }^{\circ} \mathrm{C}\right]\right)$, mean temperature $\left(\mathrm{T}_{\text {mean }}\left[{ }^{\circ} \mathrm{C}\right]\right)$, mean wind speed (wind speed $[\mathrm{m} / \mathrm{s}]$ ), and daily insolation (insolation, [\%]). The meteorological data were provided by the Institute of Meteorology and Water Management of the National Research Institute for the Kielce-Suków station [23]. The effect of meteorological factors on the concentration of pollen grains was assessed using the non-parametric Spearman correlation (STATISTICA 10.0, Statsoft, Poland). The level of $\mathrm{p}<0.05$ was assumed as statistically significant.

\section{Results and discussion}

The characteristics of the pollen seasons of oak and hornbeam in Kielce in 2021 are shown in table 1 . The relationships between the meteorological 
factors and the total and main oak and hornbeam pollen seasons are presented in table 3. Figures 1A, B and 2A, $\mathrm{B}$ show the dynamics of pollen release by the plant taxa relative to the meteorological conditions described in table 2.

In 2021, the first oak pollen grains in the air of Kielce were recorded on April 29 ${ }^{\text {th }}$. The main pollen season, determined with the $98 \%$ method, began on May $4^{\text {th }}$ and ended on June $7^{\text {th }}$. The seasonal pollen index (SPI) was estimated at 1533, and the maximum concentration of oak pollen $\left(227 \mathrm{P} / \mathrm{m}^{3}\right.$ of air) was recorded on May $20^{\text {th }}$. During the total pollen season, there were 25 days with pollen concentrations exceeding the first threshold value of $16 \mathrm{P} / \mathrm{m}^{3}$, and pollen grain concentrations exceeding $91 \mathrm{P} / \mathrm{m}^{3}$ of air were recorded on only 3 days (tab. 1, fig. 1A, B). The presence of the last oak pollen grains in Kielce bioaerosol was detected on June $12^{\text {th }}$ (fig. 1A, B). The oak pollen release is highly variable. Even during one season, the intensity of pollen release by this plant differs between the different regions of Poland. As shown by literature data, the main oak pollen season in Kielce in 2021 was delayed in comparison with the seasons in 2019 and 2020 in other Polish cities. The length of the pollen season was comparable $[2,5]$. It is possible that the lower temperatures in the early spring may have contributed to the later onset of the oak pollen season. Literature data show that oak pollen is released abundantly, and the peak pollen season occurs immediately after the appearance of the first pollen grains in the air [4].

Table 1. Characteristics of oak and hornbeam pollen seasons in Kielce in 2021.

\begin{tabular}{|c|c|c|c|c|c|c|c|}
\hline \multirow[t]{2}{*}{ Taxon } & \multicolumn{2}{|c|}{ Duration of pollen season } & \multirow{2}{*}{$\begin{array}{l}\text { Peak } \\
\text { value } \\
{\left[\mathrm{P} / \mathrm{m}^{3}\right]}\end{array}$} & \multirow{2}{*}{$\begin{array}{l}\text { Peak date } \\
\text { (day of } \\
\text { year) }\end{array}$} & \multirow{2}{*}{$\begin{array}{l}\text { Seasonal } \\
\text { pollen } \\
\text { index (SPI) }\end{array}$} & \multicolumn{2}{|c|}{$\begin{array}{l}\text { Number of days with concentration } \\
\text { above threshold }\end{array}$} \\
\hline & Start (day of year) & End (day of year) & & & & $\geq 16 \mathrm{P} / \mathrm{m}^{3}$ & $\geq 91 \mathrm{P} / \mathrm{m}^{3}$ \\
\hline Oak (Quercus) & $4.05(124)$ & 7.06 (158) & 227 & $20.05(140)$ & 1533 & 25 & 3 \\
\hline Hornbeam (Carpinus) & $10.04(100)$ & $4.06(155)$ & 22 & $28.04(118)$ & 207 & 3 & 0 \\
\hline
\end{tabular}

Table 2. Characteristics of meteorological factors during the total and main oak and hornbeam pollen seasons in Kielce in 2021.

\begin{tabular}{|c|c|c|c|c|c|}
\hline \multirow{2}{*}{\multicolumn{2}{|c|}{ Meteorological factors }} & \multicolumn{2}{|c|}{ Oak (Quercus) } & \multicolumn{2}{|c|}{ Hornbeam (Carpinus) } \\
\hline & & \multirow{2}{*}{$\begin{array}{l}\text { Total pollen season }(n=45) \\
27.2(11.05)\end{array}$} & \multirow{2}{*}{$\begin{array}{l}\text { Main pollen season }(\mathrm{n}=35) \\
27.2(11.05)\end{array}$} & \multirow{2}{*}{$\begin{array}{l}\text { Total pollen season }(\mathrm{n}=78) \\
27.2(11.05)\end{array}$} & \multirow{2}{*}{$\begin{array}{l}\text { Main pollen season }(\mathrm{n}=\mathbf{5 6}) \\
27.2(11.05)\end{array}$} \\
\hline $\mathrm{T}_{\max }$ & $\max$ & & & & \\
\hline & $\min$ & $8.3(3.05)$ & $12.3(7.05)$ & $3.0(14.04)$ & $3.0(14.04)$ \\
\hline & mean & 19.19 & 18.96 & 15.98 & 15.75 \\
\hline & SD & 4.31 & 3.77 & 5.97 & 5.34 \\
\hline \multirow{4}{*}{$\mathrm{T}_{\text {mean }}$} & $\max$ & $20.1(11.05)$ & $20.1(11.05)$ & $20.1(11.05)$ & $20.1(11.05)$ \\
\hline & $\min$ & $5.2(3.05)$ & $7.0(8.05)$ & $-1.1(7.04)$ & $0.9(14.04)$ \\
\hline & mean & 13.21 & 13.04 & 9.97 & 10.07 \\
\hline & SD & 3.55 & 3.11 & 5.23 & 4.35 \\
\hline \multirow[t]{4}{*}{$\mathrm{T}_{\min }$} & $\max$ & $12.8(9.06)$ & $12.6(5.06)$ & $12.8(9.06)$ & $11.3(14.05)$ \\
\hline & $\min$ & $-2.6(4.05)$ & $-2.6(4.05)$ & $-6.0(7.04)$ & $-3.9(26.04)$ \\
\hline & mean & 6.87 & 6.77 & 4.12 & 4.48 \\
\hline & SD & 3.41 & 3.53 & 4.60 & 4.02 \\
\hline \multirow[t]{4}{*}{ Wind speed } & $\max$ & $5.1(2.05)$ & $4.6(11.05)$ & $5.1(2.05)$ & $5.1(2.05)$ \\
\hline & $\min$ & $0.9(1.06)$ & $0.9(1.06)$ & $0.9(1.06)$ & $0.9(1.06)$ \\
\hline & mean & 2.63 & 2.61 & 2.59 & 2.75 \\
\hline & SD & 0.90 & 0.88 & 0.87 & 0.86 \\
\hline \multirow[t]{4}{*}{ Insolation } & $\max$ & $14.2(9.05)$ & $14.2(9.05)$ & $14.2(9.05)$ & $14.2(9.05)$ \\
\hline & $\min$ & 0 (2 days) & 0 ( 2 days) & 0.0 (7 days) & 0.0 (7 days) \\
\hline & mean & 7.41 & 7.53 & 6.57 & 6.38 \\
\hline & SD & 4.20 & 4.06 & 4.27 & 4.38 \\
\hline
\end{tabular}

SD - standard deviation. 
The oak pollen season in Kielce in 2021 had a compact character. The aerobiological analysis revealed that there were only two days with the highest pollen concentrations (over $200 \mathrm{P} / \mathrm{m}^{3}$ ) (fig. 1A, B). The oak and hornbeam pollen seasons overlapped.

The hornbeam pollen season was longer than in the case of oak (fig. 1A-2B). It started on the last decade of March and ended in the first half of June, as in the case of oak (fig. 2A, B). The main pollen season lasted 56 days, i.e. from April $10^{\text {th }}$ to June $4^{\text {th }}$. The peak hornbeam pollen season was observed on April 28 $8^{\text {th }}$, when 22 pollen grains in $1 \mathrm{~m}^{3}$ of air were recorded, with the annual sum of 207. Literature data indicate that the hornbeam pollen season is typically short with variable amounts of pollen released into the atmosphere [11]. The study conducted in Kielce in 2021 showed that, although the annual sum and maximum concentrations of hornbeam pollen grains were not high, the pollen season of this plant was substantially longer than in other regions of Poland in previous years [11].

Figure 1. Oak (Quercus) pollen count in Kielce in 2021 in relation to selected meteorological factors: maximum $\left(T_{\text {max }}\right)$, minimum $\left(T_{\text {min }}\right)$, and mean temperature $\left(T_{\text {mean }}\right)(A)$, insolation, and wind speed $(B)$.
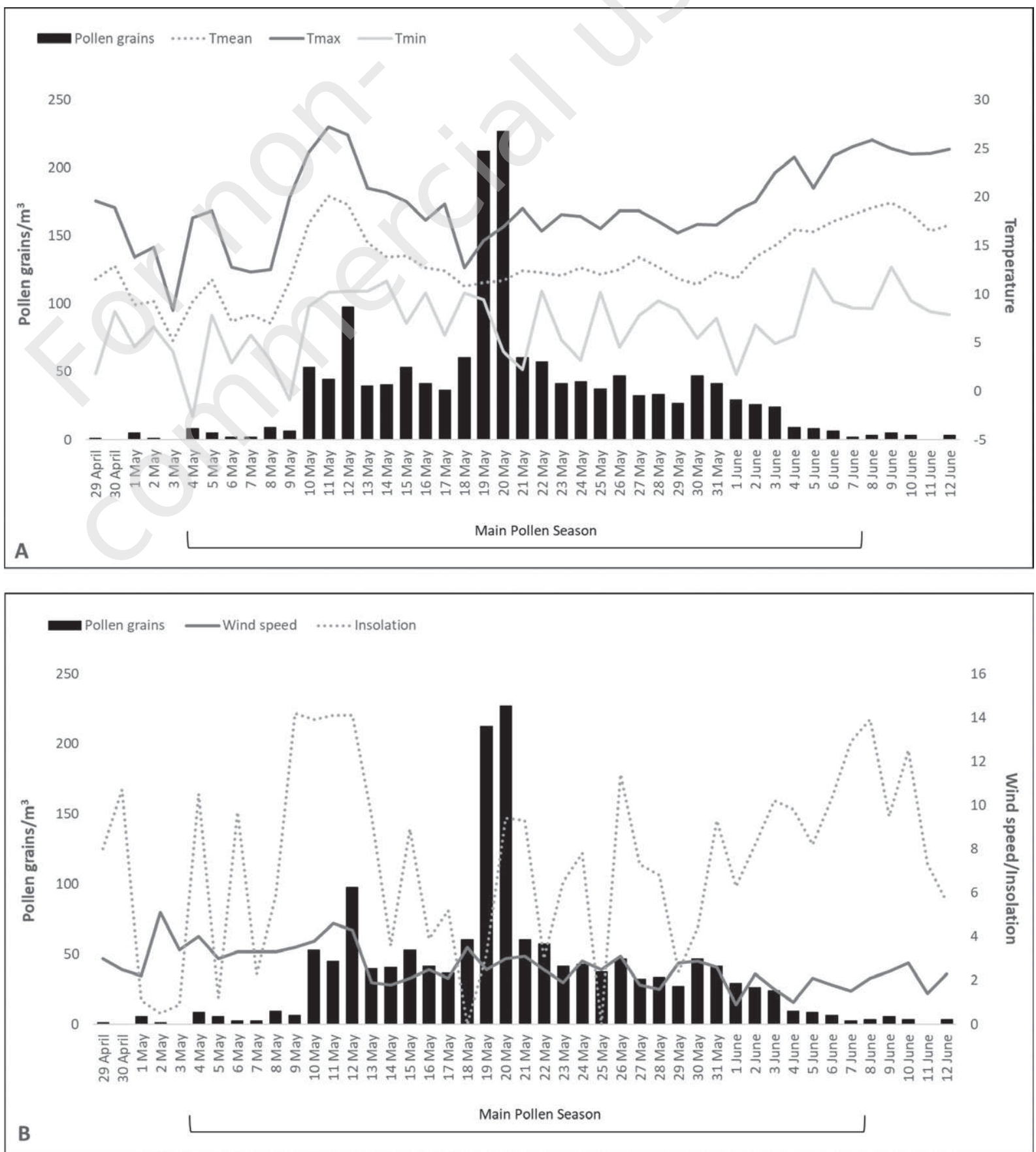
Figure 2. Hornbeam (Carpinus) pollen count in Kielce in 2021 in relation to meteorological factors: maximum $\left(T_{\max }\right)$, minimum $\left(T_{\min }\right)$, and mean temperature $\left(T_{\text {mean }}\right)(A)$, insolation, and wind speed $(B)$.
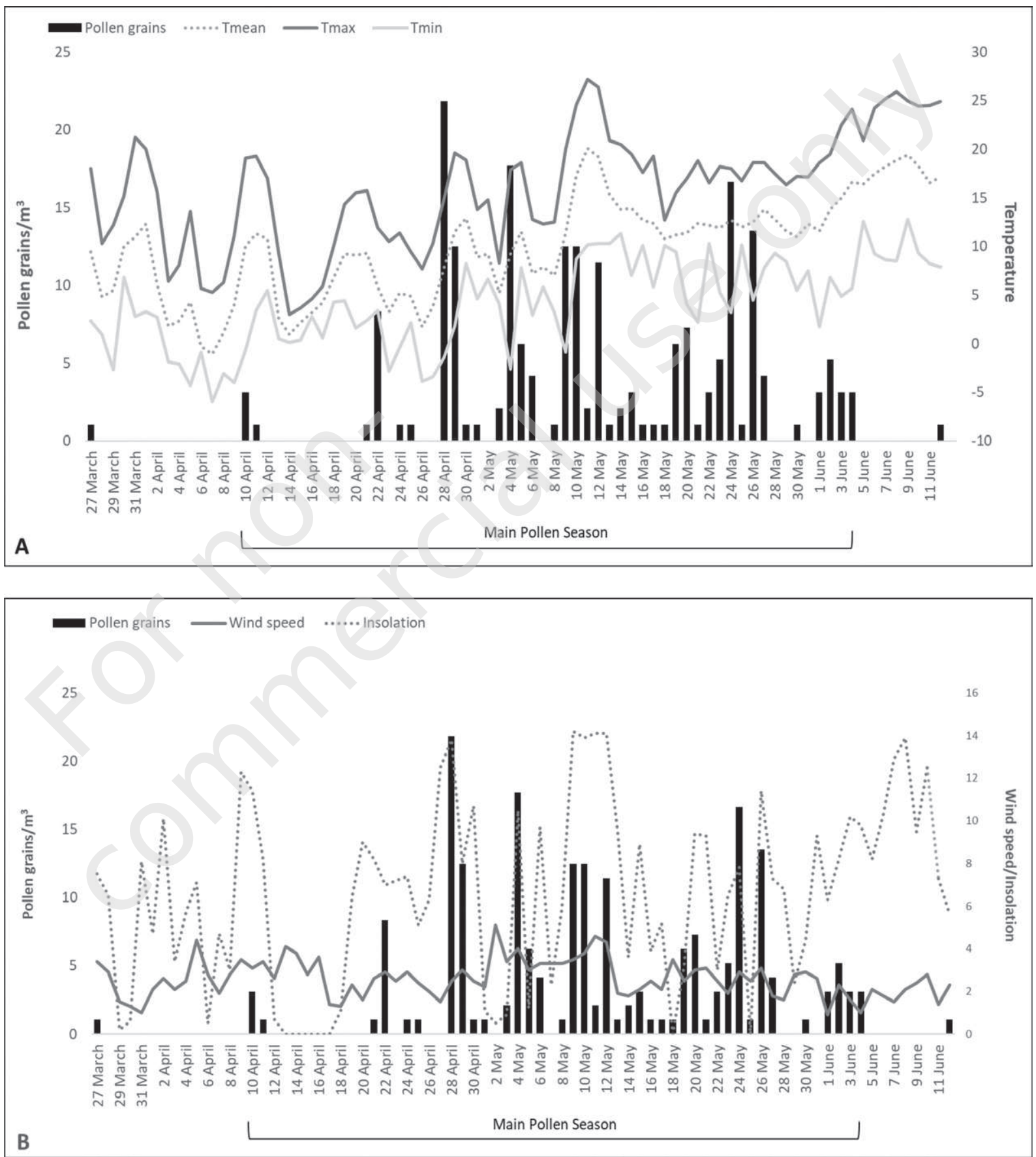

Moreover, the peak hornbeam pollen season in Kielce recorded on April $28^{\text {th }}$ coincided with the maximum concentration of maple pollen grains [24]. During the entire hornbeam pollen season in Kielce, the threshold value of the concentration of pollen grains $\left(16 \mathrm{P} / \mathrm{m}^{3}\right)$ was exceeded on only 3 days. No values exceeding 91 $\mathrm{P} / \mathrm{m}^{3}$ were recorded during the study (tab. 1, fig. 2A, B), which may indicate a low risk of intensification of allergic symptoms in allergic subjects. The hornbeam pollen season exhibited high dynamics, with four periods of more intense pollen release between the end of April and the end of May (fig. 2A, B).

As reported by Ianovici and Bîrsan [25], the concentration of airborne pollen grains may increase with increasing temperature. Hence, the impact of the maximum, minimum, and mean temperature on the oak and hornbeam pollen concentration in the air was analyzed in the present study. During the oak and hornbeam pollen seasons, the highest values of maximum temperature $\left(\mathrm{T}_{\max }\right)\left(27.2^{\circ} \mathrm{C}\right)$ and mean temperature 
$\mathrm{T}_{\text {mean }}\left(20.1^{\circ} \mathrm{C}\right)$ were recorded on May $11^{\text {th }}$. In turn, the highest value of the minimum air temperature $\left(\mathrm{T}_{\min }\right)$ $\left(12.8^{\circ} \mathrm{C}\right)$ was noted on June $9^{\text {th }}$ during the total oak and hornbeam pollen seasons. The highest minimum temperature $\left(\mathrm{T}_{\min }\right)\left(12.6^{\circ} \mathrm{C}\right)$ was recorded on June $5^{\text {th }}$ during the main oak pollen season and on May $14^{\text {th }}$ during the main hornbeam pollen season $\left(11.3^{\circ} \mathrm{C}\right)$. The highest wind speed $(5.1 \mathrm{~m} / \mathrm{s})$ was recorded on May $2^{\text {nd }}$ during the total oak pollen season and the total and main hornbeam pollen seasons. The maximum wind value of $4.6 \mathrm{~m} / \mathrm{s}$ was recorded on May $11^{\text {th }}$ during the main oak pollen season. The maximum insolation $(14.2 \%)$ was noted on May $9^{\text {th }}$ during the total and main oak and hornbeam pollen seasons (tab. 2).

Literature data show a significant impact of meteorological factors on the intensity of plant pollen release [24-27]. The present study demonstrated that not all meteorological factors exerted a significant effect on the pollen seasons of the analyzed plant taxa. Despite the similar or the same values (especially the maximum values) of most of the meteorological parameters during the oak and hornbeam pollen seasons, the correlation coefficients exhibited large differences (tab. 3). The statistical analyses revealed that the con- main hornbeam pollen season. The analyses showed no correlation between the hornbeam pollen concentration and the minimum air temperature in the total and main pollen seasons (tab. 3).

The length and date of the onset of the plant pollen season as well as the pollen season dynamics may depend on many factors. The impact of meteorological factors on the course of the pollen season in many plant species is indisputable as well. Majeed et al. [27] reported a significant influence of meteorological factors on the dynamics of plant pollen release. The air temperature, in particular the maximum and mean temperature, and insolation were the main meteorological variables exerting the greatest impact on the release or increase in pollen grain concentrations during the pollen season [27], which was also confirmed in our study. Currently, great importance is attached to research focused on determination of the relationship between the pollen count and meteorological variables. This facilitates prediction of pollen seasons and the preparation of pollen calendars for a given region. The present aerobiological study will help to determine the seasonality of pollen in allergenic plants and to prepare multiyear pollen calendars for Kielce.

Table 3. Spearman's correlation coefficients between oak and hornbeam pollen counts and meteorological factors during the total and main pollen seasons in Kielce in 2021.

\begin{tabular}{|c|c|c|c|c|}
\hline \multirow{2}{*}{ Meteorological factors } & \multicolumn{2}{|l|}{ Oak (Quereus) } & \multicolumn{2}{|l|}{ Hornbeam (Carpinus) } \\
\hline & Total pollen season $(n=45)$ & Main pollen season $(n=35)$ & Total pollen season $(\mathrm{n}=78)$ & Main pollen season $(n=56)$ \\
\hline $\mathrm{T}_{\max }$ & -0.0889 & -0.0755 & $0.3568^{\star *}$ & $0.5642^{* \star *}$ \\
\hline$T_{\text {mean }}$ & 0.0431 & 0.0754 & $0.3492^{* *}$ & $0.4634^{\star * *}$ \\
\hline$T_{\min }$ & 0.1814 & 0.2243 & 0.1755 & 0.1083 \\
\hline Wind speed & 0.1202 & 0.2347 & $0.2493^{*}$ & 0.0888 \\
\hline Insolation & -0.0036 & -0.0697 & $0.3299 * *$ & $0.5298^{* * *}$ \\
\hline
\end{tabular}

${ }^{\star} p<0.05,{ }^{* *} p<0.01,{ }^{* \star *} p<0.001$.

centration of oak pollen grains in the air of Kielce was not significantly correlated with the meteorological parameters (tab. 3). However, the weather conditions exerted a significant effect on the hornbeam pollen concentration. A statistically significant positive correlation was found between the number of hornbeam pollen grains and the maximum air temperature $\left(\mathrm{T}_{\max }\right)$ during the total (at $\mathrm{p}<0.01$ ) and main (at $\mathrm{p}<0.001$ ) pollen seasons. A similar correlation was confirmed for the mean air temperature and the insolation degree (tab. 3). The present study also revealed a significant correlation between the mean wind speed and the total hornbeam pollen season (at $\mathrm{p}<0.05$ ). However, the wind speed did not exert any significant effect on the

\section{Conclusions}

1. In the 2021 season, the first hornbeam pollen grains were recorded in the bioaeroplankton in Kielce on the last days of March and the onset of the oak pollen season was noted on the last days of April. Oak and hornbeam pollen persisted in the atmosphere until the second ten days of June.

2. The main oak pollen season was compact with intense pollen release recorded on the second ten days of May. The hornbeam pollen season was dynamic with four peaks of more intense pollen release recorded between the end of April and the end of May. 
3. A varied effect of meteorological parameters on the oak and hornbeam pollen seasons in 2021 was observed. The maximum $\left(\mathrm{T}_{\max }\right)$ and mean $\left(\mathrm{T}_{\text {mean }}\right)$ air temperature and insolation had a significant effect on the total and main hornbeam pollen seasons. Additionally, the mean wind speed exerted a significant impact on the total pollen season of this taxon.

\section{References:}

1. Piotrowska-Weryszko K, Weryszko-Chmielewska W. Plant pollen content in the air of Lublin (central-eastern Poland) and risk of pollen allergy. Ann Agric Environ Med. 2014; 21(4): 693-6. http://doi.org/10.5604/12321966.1129916.

2. Rapiejko A, Malkiewicz M, Ziemianin M et al. Oak pollen concentration in the air of selected Polish cities in 2020. Alergoprofil. 2020; 16(4): 15-20. http://doi.org/10.24292/01. AP.1643311220.3.

3. Rapiejko P. Alergeny pytku dębu. Alergoprofil. 2007; 3(3): 34-8.

4. Lipiec A, Puc M, Malkiewicz M et al. Analiza stężenia pyłku dębu $w$ wybranych miastach Polski w 2015 r. Alergoprofil. $2015 ; 11(3): 45-9$.

5. Dąrowska-Zapart K, Chłopek K, Malkiewicz M et al. Oak pollen season in selected cities of Poland in 2019. Alergoprofil. 2019; 15(2): 12-6. http://doi.org/10.24292/01. AP.152150919.

6. Szafer W, Kulczyński S, Pawłowski B. Rośliny Polskie. PWN, Warszawa 1988.

7. Puc M, Myszkowska D, Chłopek K et al. Oak pollen in the air of Poland in 2017. Alergoprofil. 2017; 13(3): 124-8. http:// doi.org/10.24292/01.ap.300917.

8. Rapiejko P, Lipiec A, Jurkiewicz D. Alergogenne znaczenie pyłku dębu. Alergia. 2004; 2: 38-41.

9. Rapiejko P, Stankiewicz W, Szczygielski K et al. Progowe stężenie pyłku roślin niezbędne do wywołania objawów alergicznych. Otolar Pol. 2007; 61(4): 591-4.

10. Burge HA. Monitoring for airborne allergens. Ann. Allergy. 1992; 9: 9-21.

11. Puc M, Kotrych D, Piotrowska-Weryszko K et al. Hornbeam pollen in the air of Poland in 2018. Alergoprofil. 2018; 14(3): 72-6. http://doi.org/10.24292/01.AP.291918.

12. Chłopek K, Rapiejko P, Lipiec A et al. Analiza stężenia pytku grabu (Carpinus) w wybranych miastach Polski w 2007 r. Alergoprofil. 2007; 3(3): 39-44.

13. Pidek IA. Carpinus betulus pollen accumulation rates in Roztocze (SE Poland) in relation to presence of Carpinus in Ferdynandovian pollen diagrams. Ecological Questions. 2017; 27: 95-101. http://doi.org/10.12775/EQ.2017.023.

14. Bachofer M, Mayer J. Drzewa. MULTICO Oficyna Wydawnicza, Warszawa 2007.
15. Pokorny J. Drzewa znane i mniej znane. Polska Oficyna Wydawnicza ,BGW”, Warszawa 1992.

16. Seneta W, Dolatowski J. Dendrologia. PWN, Warszawa 2008.

17. Mattiesen F, Ipsen H, Lowenstein H. Pollen allergens. In: D’Amato G, Spieksma FTM, Bonini S (ed). Allergenic pollen and pollinosis In Europe. Blackwell Scientific Public, London 1991: 36-44. mined by cross-hybridization. J. Allergy Clin. Immunol. 1991, 87(3): 677-82

18. Valenta R, Breiteneder H, Petternburger K et al. Homology of the major birch-pollen allergen, Bet $v I$, with the major pollen allergens of alder, hazel and hornbeam at the nucleic acid level as determined by cross-hybridization. J Allergy Clin Immunol. 1991; 87(3): 677-82.

19. Rapiejko P. Wybrane aspekty alergii krzyżowej. Alergoprofil. 2006; 2(2): 11-5.

20. Lipiec A, Puc M, Kalinowska E et al. Pyłek grabu w powietrzu wybranych miast Polski w 2014 r. Alergoprofil. 2014; 10(3): 48-53.

21. Gumowski PI, Clot B, Davet A et al. The importance of hornbeam (Carpinus sp.) pollen hypersensitivity in spring allergies. Aerobiologia. 2000; 16: 83-6.

22. Emberlin J, Savage M, Jones S. Annual variations in grass pollen seasons in London 1961-1990: trends and forecast models. Clin Exp Allergy. 1993; 23(11): 911-8.

23. Instytut Meteorologii i Gospodarki Wodnej-Państwowy Instytut Badawczy. www.meteomodel.pl (access: 27.07.2021).

24. Ślusarczyk J, Kopacz-Bednarska A, Postowska J. Characteristics of ash, maple, yew/juniper, and willow pollen seasons in the air of Kielce in 2021 in correlation with weather conditions. Alergoprofil. 2021; 17(4): 3-10. http://doi. org/10.24292/01.AP.174181021.

25. Ianovici N, Bîrsan MV. The influence of meteorological factors on the dynamic of Ambrosia artemisiifolia pollen in an invaded area. Not Bot Horti Agrobo. 2020; 48(2): 752-69. http://doi.org/10.15835/nbha48211862.

26. Dąbrowska-Zapart K, Chłopek K, Niedźwiedź T. The impact of meteorological conditions on the concentration of alder pollen in Sosnowiec (Poland) in the years 1997-2017. Aerobiologia. 2018; 34: 469-85. http://doi.org/10.1007/s10453018-9524-8.

27. Majeed HT, Periago C, Alarcón M et al. Airborne pollen parameters and their relationship with meteorological variables in NE Iberian Peninsula. Aerobiologia. 2018; 34: 375-88. http://doi.org/10.1007/s10453-018-9520-z.

ORCID

A. Kopacz-Bednarska - ID - http://orcid.org/0000-0003-0664-1450

J. Posłowska - ID - http://orcid.org/0000-0002-6310-0688

J. Ślusarczyk - ID - http://orcid.org/0000-0001-8022-3244

Authors' contributions:

A. Kopacz-Bednarska: 45\%; J. Posłowska: 10\%; J. Ślusarczyk: 45\%.

Conflict of interests:

The authors declare that they have no competing interests. 
Financial support:

This study was partially funded by research funds for 2022 as a research project SUPB. RN.21.247.

Ethics:

The contents presented in this paper are compatible with the rules the Declaration of Helsinki, EU directives and standardized requirements for medical journals.

Research in Kielce.

Copyright: (C) Medical Education sp. z 0.0. This is an Open Access article distributed under the terms of the Attribution-NonCommercial 4.0 International (CC BY-NC 4.0). License (https://creativecommons.org/licenses/by-nc/4.0/), allowing third parties to copy and redistribute the material in any medium or format and to remix, transform, and build upon the material, provided the original work is properly cited and states its license.

\section{Correspondence}

Joanna Ślusarczyk, MD, PhD, Assoc. Prof.

Department of Environmental Biology, Institute of Biology, Jan Kochanowski University in Kielce, 25-406 Kielce, Uniwersytecka 7 e-mail: joanna.slusarczyk@ujk.edu.pl

(c) Medical Education. For private and non-commercial use only. Downloaded from https://www.journalsmededu.pl/index.php/alergoprofil: 26.04.2023; 12:06,56 